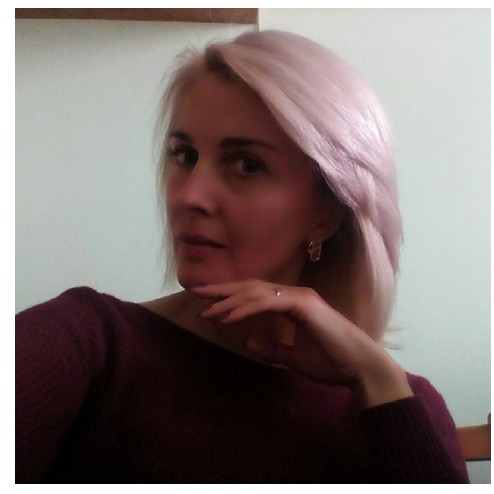

\author{
Наталія Матвеєва, \\ кандидат педагогічних наук, доцент \\ кафедри педагогіки початкової освіти \\ ДВНЗ «Прикарпатський національний \\ університет імені Василя Стефаника» \\ (м. Івано-Франківськ, Україна)
}

\author{
Nataliia Matveyeva, \\ $\mathrm{PhD}$ in Education, Associate Professor, \\ Department of Pedagogy of Primary Education, \\ Vasyl Stefanyk Precarpathian National University \\ (Ivano-Frankivsk, Ukraine) \\ nataliematveieva@gmail.com \\ ORCID ID 0000-0002-8495-7074
}

удКЗ7.011.31:371.14

\title{
СПЕЦИФІКА НАВЧАННЯ МОЛОДШИХ ШКОЛЯРІВ З ПОРУШЕННЯМИ ЗОРУ
}

Анотація. У статті наголошено, що особливо актуальною сьогодні є проблема навчання, виховання та розвитку осіб з особливими освітніми потребами, а зокрема з порушеннями зору. Позаяк чисельність осіб з даною нозологією щорічно зростає, про що засвідчують статистичні дані Міністерства охорони здоров'я України, актуалізується необхідність пошуку нових підходів до навчання та виховання молоді; вибору нетрадиційних форм, методів, прийомів та засобів навчання дітей шкільного віку з порушеннями зору. Розв'язання цього та низки інших супровідних завдань мають на меті створення належного комфортного середовища, у якому учням було б затишно перебувати поряд з іншими школярами, успішно навчатись, опановувати пожиттєво необхідні компетенції, розвивати свої задатки та здібності, реалізовувати творчий потенціал.

Натомість особливо важливим є подолання низки труднощів, що мають місце у процесі упровадження інклюзивної моделі навчання, позаяк саме вони призводять до гальмування даного процесу загалом та призводять до виникнення різноманітних перешкод у життєдіяльності учнів.

Мета дослідження полягала у виокремленні низки особливостей даної категорії молодших школярів, встановленні їх реальних можливостей щодо здійснення навчання у школі та визначенні специфіки навчально-виховної діяльності вчителів у роботі із ними; встановленні переліку вимог до діяльності вчителя задля попередження появи певних труднощів у процесі навчання; встановленні рівня готовності учнів із порушеннями зору до навчання у загальноосвітньому навчальному закладі.

У процесі нашого дослідження нами було використано наступні методи, а саме:теоретичні (опрацювання літературних джерел, нормативно-правової бази інклюзивної освіти); емпіричні (анкетування, опитування, спостереження, етичні бесіди, ранжування, експертне оцінювання, методи статистичної обробки даних).

Результати нашого дослідження ще раз підтвердили вже існуючі гіпотези низки науковців про те, що у випадку включення дітей із різними видами нозологій на навчання у ЗОШ необхідно ретельно вивчити їх особливості та можливості, своєчасно діагностуючи індивідуальні можливості, задатки, рівень научуваності, особливості учнів; накреслити основні шляхи задля підвищення ефективності створення інклюзивного середовища у навчальному закладі; здійснювати інноваційну діяльність задля надання якісних освітніх послуг молодшим школярам з порушеннями зору.

Ключові слова: особливі потреби, порушення зору, успішність, адаптація, навчальне середовище, інклюзивне навчання, включення, педагог, індивідуальний підхід, можливості.

\section{SPECIFICITY OF TEACHING JUNIOR STUDENTS WITH VISUAL IMPAIRMENT}

Abstract. The article emphasizes that today the problem of teaching, upbringing and development of people with special educational needs, and in particular with visual impairment, is especially relevant. As the number of individuals with this nosology grows annually, as evidenced by the statistics of the Ministry of Health of Ukraine, the need to find new approaches to youth education and upbringing is updated; the choice of non-traditional forms, methods, methods and means of teaching children of school age with visual impairment. The solution to this and a number of other accompanying tasks is to create a comfortable environment in which students would be comfortable with other students, to successfully learn, to master the vital competences, to develop their skills and abilities, to realize their creative potential.

Instead, it is particularly important to overcome a number of difficulties that occur in the process of introducing an inclusive model of learning, as they preclude the inhibition of this process as a whole and lead to a variety of impediments to the life of students.

The purpose of the study was to highlight a number of peculiarities of this category of junior pupils, to establish their real opportunities for exercising in school and to determine the specifics of the teaching and educational activities of teachers in working with them; establish a list of requirements for the activities of the teacher in order to prevent the emergence of 
certain difficulties in the learning process; to establish the level of readiness of pupils with visual impairments before studying in a general educational institution.

In the process of our study, we used the following methods, namely: theoretical (working out literary sources, normativelegal basis of inclusive education); empirical (questionnaires, surveys, observations, ethical conversations, rankings, expert evaluation, methods of statistical processing of data).

The results of our study once again confirmed the already existing hypotheses of a number of scholars that, in the case of the inclusion of children with different types of nosology's for studying in secondary schools, it is necessary to carefully examine their peculiarities and possibilities by timely diagnosing the individual possibilities, factors, learning levels, peculiarities of students; outline the main ways to increase the effectiveness of creating an inclusive environment in an educational institution; To carry out innovative activities for the provision of quality educational services for younger students with visual impairment.

Keywords: special needs, visual impairment, success, adaptation, learning environment, inclusive education, inclusion, teacher, individual approach, opportunities.

\section{ВСТУП}

Постановка проблеми. Реалії сьогодення чітко виокремлюють низку проблем, які потребують ретельного вивчення, визначення шляхів попередження подальшої їх появи та подолання. Стрижневою з-поміж них є потреба визначення пріоритетів, засобів підвищення ефективності щодо створення комфортних умов життєдіяльності, навчання, виховання, розвитку осіб з особливими потребами. Натомість постійне зростання чисельності таких осіб й, особливо, шкільного віку, потребує акцентування уваги на новій моделі освіти - інклюзивному навчанні, що передбачає включення даної категорії дітей на навчання у школи за місцем проживання чи побажанням замовників.

Відповідно до Концепції Нової Української Школи, сучасний навчальний заклад покликаний сприяти становленню дитини як неповторної індивідуальності, розвивати їі творчий потенціал та прагнення до самореалізації. За такого підходу, розвиток в Україні інклюзивної освіти виступає найбільш ефективним серед низки шляхів щодо розв'язання даної проблеми, позаяк дана освітня модель націлена на залучення дітей із особливими освітніми потребами в освітній процес, дозволяє задоволення освітніх потреб, забезпечення необхідних умов самореалізації та самоствердження особистості (Родименко I, 2017 с. 205). Стрижневе завдання інклюзивної освіти полягає в створенні нової школи - школи діалогу, взаєморозуміння, співпраці, творцями якої виступають діти спільно 3 учителями. А, отже, питання включення дітей шкільного віку з особливими потребами на навчання у загальноосвітні навчальні заклади є особливо актуальним й потребує подальшого поглибленого вивчення.

META I ЗАВДАННЯ ДОсЛІДЖЕННЯ. Мета - розкрити специфіку навчання учнів із порушеннями зору у загальноосвітньому навчальному закладі; виокремити основні чинники впливу на успішність даної категорії школярів та накреслити шляхи підвищення ефективності навчально-виховного процесу. Виходячи із означеної мети, нами було виокремлено наступні завдання дослідження:

1) діагностувати рівень готовності та соціальної адаптованості молодших школярів із порушеннями зору до навчання в умовах школи;

2) вивчити психолого-педагогічні особливості учнів з порушеннями зору;

3) дослідити основні чинники впливу на успішність учнів з порушеннями зору тощо.

МЕТОДИ ДОслІДЖЕНня: У процесі дослідження нами було використано теоретичні (опрацювання літературних джерел, нормативно-правової бази інклюзивної освіти) та емпіричні(анкетування, опитування, спостереження, етичні бесіди, ранжування, експертне оцінювання, методи статистичної обробки даних)методи дослідження. Загалом у ході нашого дослідження ми намагались якомога краще розкрити особливості даних учнів, вивчити їх можливості та задатки з тим, щоб здійснювати індивідуальний підхід у процесі навчання задля підвищення успішності, розвитку творчого потенціалу, створення комфортних умов співпраці тощо. Зокрема опитування учителів, батьків та їх дітей ми поєднували з систематичним спостереженням за молодшими школярами, здійснювали аналіз та оцінку отриманих результатів, робили висновки.

\section{РЕЗУЛЬТАТИ ДОСЛІДЖЕННЯ}

Інклюзивна освіта сьогодні має на меті розбудову інклюзивного суспільства, у якому цінують й поважають один одного; створення безбар'єрного простору щодо участі у житті суспільства усіх громадян, незалежно від етнічної приналежності, віку й статі, здібностей, наявності чи відсутності особливостей у психофізичному розвитку. Своєю чергою це потребує розробки підходів до навчального процесу, який буде гнучким щодо задоволення різноманітних запитів дітей з особливими освітніми потребами, що узалежнюється низкою чинників (адаптація та модифікація навчальних програм, навчальних матеріалів, самого приміщення закладу тощо). У контексті означеної проблеми особливого значення набуває адаптація навчального середовища з тим, щоб діти з порушеннями зору почували себе зручно, могли успішно навчатися, були активними у житті школи та громади (Колупаєва А, 2017, с. 12).

Практика засвідчує, що у більшості шкіл України майже третина учнів різного віку мають дані порушення. До прикладу, щорічно близько 250 тис. дітей віком від народження до 18 років втрачає зір. Згідно статистичних даних, щороку у дітей в Україні реєструється 840 тис. випадків офтальмологічних захворювань, причому сьогодні проживає 10,7 тис. незрячих і слабозорих дітей, чисельність яких з кожним роком зростає ще на 1 тис. осіб. Характерно, згідно результатів щорічних профілактичних оглядів школярів, частота виявлення учнів із зниженою гостротою зору за час навчання у школі зростає у три-п'ять разів і на завершення навчання становить $30 \%$ (Костецька, А.О., 2014). Ці та інші дані дозволяють стверджувати про те, що питання специфіки навчання даної 
категорії учнів потребує особливої уваги як з боку вчителів, фахівців навчального закладу, батьків, так само й громадськості, науковців, соціологів, медиків та ін.

У ході вивчення психолого-педагогічних особливостей молодших школярів з порушеннями зору нами було обрано експериментальну базу дослідження (ЗОШ № 21 м. Івано-Франківська) й встановлено, що дітей з даними порушеннями у четвертих класах (загальна кількість 61 учень) - 28 осіб, тобто 45,9\% від загальної кількості учнів. У ході нашого дослідження ми намагалися шляхом спостереження за школярами встановити їх індивідуальні можливості та особливості, методом опитування та анкетування діагностувати рівень готовності до навчання, відповідність умов навчального закладу потреба даної категорії школярів.

Аналіз реалій шкільної практики показав, що учні з порушеннями зору мають низку проблем у навчанні, спровокованих зниженням гостроти та поля зору, а також порушеннями просторового зору. 3 одного боку, це викликає труднощі у пересуванні, орієнтуванні у просторі, а з іншого - в навчанні, а саме: опануванні письма, виконанні завдань різного характеру. Загалом такі порушення провокують зниження рівня уваги, що зумовлює відставання у навчанні внаслідок зниження активності на уроці, потреби збільшення часових обмежень у процесі виконання завдань тощо. Натомість, в учнів з серйозними порушеннями зору можливе виникнення спотвореного сприйняття навколишнього світу, збіднення уявлення, зниження рівня та обсягу запам'ятовування. Як результат - діти із порушеннями зору значно швидше втомлюються, а це зумовлює низький рівень фізичної та розумової працездатності.

Нами встановлено, що специфіка навчання даної категорії учнів відповідно до їх особливостей полягає у підсиленні сприймання ними навчального матеріалу, що своєю чергою вимагає створення належних умов навчання та розвитку під час перебування у навчальному закладі. До прикладу, такі учні потребують додаткового аудіо-супроводу інформації (на уроках читання, «я і Україна», образотворчого мистецтва, трудового навчання та ін.). 3 іншого боку, на особливу увагу заслуговує виважений підхід учителя до виконання письмових робіт (збільшення часу на виконання завдань; супровід наочного демонстрування поясненням та тлумаченням; виготовлення додаткового наочного матеріалу на матовому папері великими літерами; тримання в полі зору таких школярів задля з'ясування того, встигає учень за ходом уроку чи ні).

Відповідно до нашого спостереження та вивчення офтальмологічних показників учнів з порушеннями зору (за медичною карткою, результатами бесіди з фахівцями школи) нами було виявлено, що: а) у більшості випадків діти із порушеннями зору були поставлені на облік як такі, що потребують його корекції; б) більшість школярів користувались спеціальними приладами для покращення зорового сприймання (окуляри) або мали незначне його зниження, яке виникло вже у процесі навчання у школі (внаслідок неправильної постави під час сидіння, близького розташування навчальних матеріалів до очей, в силу інших причин); в) більшість учнів мали дане порушення з раннього віку й лише декілька (5 учнів) набутого характеру (з моменту початку навчання у школі); г) учні швидко стомлювались на уроках, потребували систематичних перерв задля відпочинку; д) щодо комфортного перебування у ЗОШ - почували себе відносно добре у порівнянні з іншими дітьми, однак іноді відчували певні труднощі на уроках в силу фізіологічних особливостей; е) прагнули добре вчитись, не дивлячись на поганий зір.

За даними проведеного анкетування з метою визначення можливих проблем щодо комфортного перебування, навчання та розвитку дітей у школі поряд з учнями з особливими освітніми потребами нами встановлено повну їх відсутність (100\%), тобто загалом у дитячому колективі учні із порушеннями зору не розглядаються як такі, що створюють певні незручності для інших учасників навчально-виховного процесу. Натомість діагностування освітнього середовища навчального закладу показало, що є потреба переглянути окремі аспекти цілісного навчального процесу задля внесення певних коректив. Так, батьки прагнули б змінити навчальну програму, тривалість уроків та навантаження учнів (45\% респондентів), ставлення до учнів (15\%), кількість учнів у класах (20\%), умови навчання (20\%) (Див. рис. 1.):

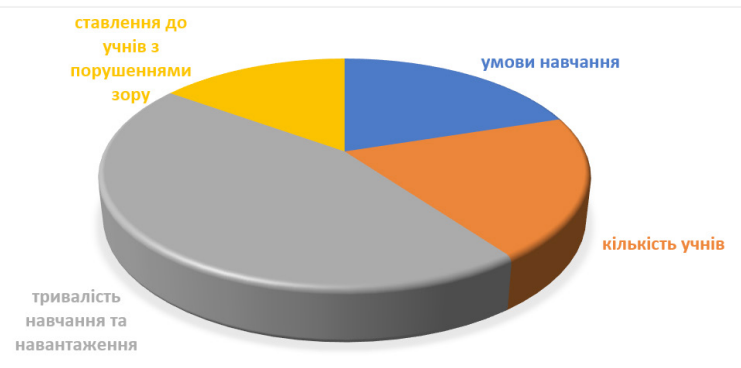

Рис. 1. Створення належних умов навчання учнів з порушеннями зору

Як показано на рис. 1, специфіка навчання учнів із порушеннями зору передовсім полягає у адаптації навчального середовища та навчальних засобів й матеріалів з тим, щоб навчально-виховний процес дозволив досягати прогнозованих результатів. Так, у ході здійснення анкетування педагогів школи нами встановлено, що усі учителі закладу готові працювати з дітьми з особливими освітніми потребами, не дивлячись на понаднормові 
витрати часу та зусиль; потребу постійного самовдосконалення, вивчення та упровадження передового педагогічного досвіду та інновацій у власній практиці.

Наше дослідження показало, що керівним принципом у процесі вибору необхідних форм та методів роботи з учнями з порушеннями зору виступає індивідуальний та особистісно-зорієнтований підхід, які дають змогу краще пізнати учня (потреби, рівень научуваності, можливості запам'ятовування, концентрування уваги, самостійності тощо) та зробити правильний вибір. Задля визначення та встановлення чітких вимог щодо специфіки навчання учнів із порушеннями зору ми прагнули передовсім диференціювати учнів за ступенем ураження ока. Опрацьовані нами офтальмологічні показники учнів, а також спостереження за їх поведінкою у процесі навчання та ігрової діяльності довели, що учнів слід розмежувати на три групи: І група - 2 осіб 3 тяжким ступенем порушення зорового сприймання (лише 25\% збереження зору); II група - 21 особа з середнім ступенем ураження ока; III група - 5 учнів, що набули дане порушення вже у процесі навчання у школі (легкий ступінь). Відповідно до цього ми ураховували той факт, що чим важчий ступінь порушення учня, тим більше труднощів може виникати у процесі «ситуативного усного мовлення». Іншими словами, молодші школярі зі складною формою порушення зору унаслідок неможливості сприймати мімічне відтворення мовлення учителя не завжди розуміли емоційну сторону мовця, а, отже, не сприймали навчальний матеріал у повному його обсязі, не могли спроектувати подальші поведінкові дії. Слід зазначити, що у процесі навчання у даних школярів було виявлено низький рівень пізнавальної активності, занижену самооцінку та труднощі у соціальній адаптації, певну ізольованість від інших дітей.

Наше дослідження дозволяє зробити висновок про те, що у процесі навчання учнів із порушеннями зору задля запобігання появи неуспішності, виникнення конфліктних ситуацій, відчуження чи непорозумінь між учнями, подолання можливих труднощів слід: а) адаптувати навчальний матеріал: розташовувати навчальні засоби не менше як за 30-33 см. від очей під кутом 5є - 45є щодо лінії погляду; виготовляти наочні матеріали на відповідному папері (матовому, а не глянцевому), з жовтою, блідо-зеленою основою; зображення та рисунки відтворювати чітко, у кольорах, яскравого кольору; дотримуватись пропорційності зображень (за величиною, кольором, формою); інформаційну ємність зображень не перенасичувати зайвим для кращого сприймання та запам'ятовування. Так, ми використовували індивідуальні картки на уроках математики, мови, написані різними за розміром літерами з дотриманням необхідного міжрядкового інтервалу з урахуванням показників учня.

б) адаптувати методики навчання: збільшувати час на виконання письмових, графічних та ін. видів завдань та вправ; здійснювати тактильний контроль за учнями;використовувати вербальний спосіб комунікації як основний у процесі оголошення завдань, теми;використовувати лише точні словесні конструкції;скоротити тривалість зорової роботи учнів до 15 хв.; систематично здійснювати чергування зорової роботи з іншими видами діяльності школярів;чітко контролювати обсяг домашніх завдань, пов'язаних із зоровою роботою та навантаженням;у процесі навчання ураховувати вікові, фізіологічні та індивідуальні особливості дітей з порушеннями, а зокрема специфічні особливості функціонування їх зорової системи.

Загалом специфіка навчання даної категорії учнів вимагає від педагога дотримання низки вимог, а саме:

- улаштувати безбар'єрний простір між робочим місцем (партою) учня та учителем (класною дошкою). Звертати увагу на освітлення робочого місця дитини (не менше 75-100 кд/м.кв.);

- весь навчальний матеріал доповнювати додатковою наочністю, прилаштованою для того чи іншого учня з порушенням зору (великі літери, жовтий колір паперу, матова поверхня паперу); слідкувати за дотриманням визначеного офтальмологом режиму (читання, письма тощо); письмове пояснення на класній дошці обов'язково супроводжувати поясненням та виконувати крейдою відповідного кольору;

- не використовувати невербальні засоби спілкування (кивання, рухи рук, міміку та ін.); тримати школяра в центрі своєї уваги (задля постійного контролю його можливого відставання);

- не переобтяжувати учнів виконанням письмових робіт (уникати опрацювання ними великих текстів під час самостійної роботи), збільшувати час на виконання письмових завдань або заміняти їх іншим видом роботи;

- стежити за поставою учня, його офтальмологічними показниками (переглядати дані медичних обстежень щодо ступеня зниження зору, зафіксовані у медичній картці дитини), фізичним та психічним станом, чистотою окулярів; систематично цікавитись у відповідних фахівців даними про використання необхідних спеціальних, звичайних чи додаткових засобів корекції зору (лінзи, окуляри, тифло-прилади, спеціальні комп'ютерні програми та ін.);

- упродовж уроку кожні 10-15 хвилин улаштовувати 1-2 хвилини розвантаження, за яких діти робитимуть спеціальні вправи для відпочинку очей;

- використовувати на уроках інноваційні методи та підходи (музикомалювання, декламація, спів, гра на шумових інструментах, ритмічні рухи, прикладне мистецтво), що слугують розвитку відтворюючої уяви під час слухання літературно-музичного твору, стимулюють творчу, художньо-образну уяву;

- тісно співпрацювати з іншими фахівцями, батьками учнів та інше.

Обговорення. Як показало наше дослідження, навчання учнів молодшого шкільного віку із порушеннями зору має відповідати не лише нормам та вимогам навчальної програми, планів, а й, передовсім, запитам самих школярів. Здійснене дослідження підтверджує гіпотези низки науковців, як-от А. Колупаєвої, Л. Савчук (Колупаєва А, 2017, с. 12), які наголошують на потребі здійснення навчання за принципом індивідуального підходу, з урахуванням особистих 


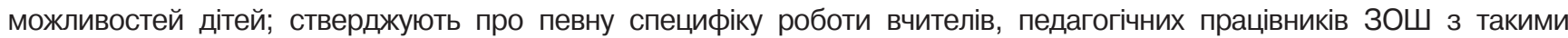
учнями.

Інші науковці Л. Будяк (Будяк Л. І., 2010, с. 10), Г. Кравченко, Г. Сіліна (Кравченко Г. Ю., \&Сіліна Г. О., 2014 с. 47), Ірина Родименко (Родименко І., 2017, с. 205), Л. Куненко (Куненко Л. О., 2009, с. 47) та ін. так само акцентують увагу на тому, що необхідно адаптувати навчальні програми та плани, фізичне середовище, форми та методи навчання) до можливостей та освітніх потреб учнів із порушеннями;використовувати усі можливі ресурси задля створення комфортних умов перебування дітей з особливими потребами у ЗОШ;працювати у «команді», залучаючи усіх без винятку педагогів, фахівців, батьків та членів громади до навчально-виховного процесу;створювати позитивний клімат у шкільному середовищі тощо.

\section{ВИСНОВКИ ТА ПЕРСПЕКТИВИ ПОДАЛЬШИХ ДОСЛІДЖЕНЬ}

Результати нашого дослідження дозволяють стверджувати, що, по-перше, діти молодшого шкільного віку із порушеннями зору, не дивлячись на труднощі, які виникають, практично готові до навчання у ЗОШ й прагнуть добре навчатись; по-друге, успішність навчання даної категорії молодших школярів узалежнюється відповідністю здійснення адаптації та модифікації навчального середовища та матеріалів, створення комфортних умов щодо задоволення потреб даних учнів відповідно до їх можливостей; по-третє, індивідуальні психофізіологічні особливості учнів молодшого шкільного віку із порушеннями зору вимагають від педагога навчального закладу дотримання низки вимог щодо специфіки роботи із учнями; вивчення передового педагогічного досвіду щодо упровадження інклюзивного навчання; систематичного підвищення власного професійного рівня, упровадження на практиці різноманітних форм та методів навчання, які дозволяють підвищити успішність молодших школярів.

\section{СПИСОК ВИКОРИСТАНИХ ДЖЕРЕЛ}

Колупаєва, А. (2017) Стратегічні вектори змін та трансформацій в освіті дітей з особливим потребами за часів незалежності в Україні. Освіта осіб з особливими потребами: шляхи розбудови: зб. наук. праць / за ред. В.В. Засенка, А.А. Колупаєвої. К.: ТОВ «Наша друкарня», Вип. 13,.12-18..

Будяк, Л.І.(2010) Організаційно-педагогічні умови інклюзивного навчання дітей з порушеннями психофізичного розвитку в за-гальноосвітній сільській школі (Автореферат дис. на здобуття наук. ступеня кандидата педагогічних наук ). Київ.

Родименко, І. (2017) Інклюзивні тенденції освітнього реформування. Освіта осіб з особливими потребами: шляхи розбудови: зб. наук. праць (За ред. В.В. Засенка, А.А. Колупаєвої). К.: ТОВ «Наша друкарня», Вип. 13, 205-208.

Кравченко, Г. Ю., \&Сіліна Г. О. (2014) Інклюзивна освіта. Х.: Вид-во «Ранок».

Куненко, Л. О. (2009) Використання арт-педагогічних методів у корекційній педагогіці. Наукові праці Чорноморського Ду ім. П.Могили. Серія: Педагогіка, Т. 108, Вип. 95, 47-50.

Matveieva, N. (2018) Inclusive Education in Schools Organizational-Pedagogical Aspect of the Problem. Jornal of V.Stefanyk PNU, Vol. 5, No 1, 80-88.

Костецька, А.О. (2014) Медико-організаційна технологія оптимізації моніторингу порушень зору у школярів. (Автореф. дис. ... канд. мед. наук). URL: https://nmapo.edu.ua/zagruzka/DrAr/ArKostecka.pdf

\section{REFERENCES}

Kolupajeva, A. (2017) Ctrateghichni vektory zmin ta transformacij v osviti ditej z osoblyvym potrebamy za chasiv nezalezhnosti v Ukrajini In Osvita osib z osoblyvymy potrebamy: shljakhy rozbudovy: zb. nauk. pracj Zasenka, V.V., Kolupajevoji, A.A. (Ed). K.: TOV «Nasha drukarnja», Vyp. 13, 12-18.

Budjak, L. I. (2010) Orghanizacijno-pedaghoghichni umovy inkljuzyvnogho navchannja ditej z porushennjamy psykhofizychnogho rozvytku v zaghaljnoosvitnij siljsjkij shkoli (Extended abstract of Candidate's thesis). Kyjiv.

Rodymenko, I. (2017). Inkljuzyvni tendenciji osvitnjogho reformuvannja (Inclusive tendencies in educational reform). Osvita osib z osoblyvymy potrebamy: shljakhy rozbudovy: zb. nauk. pracj (Ed. V.V. Zasenka, A.A. Kolupajevoji). K.: TOV «Nasha drukarnja», Vyp. 13, 205-208.

Kravchenko, Gh. Ju., \&Silina, Gh. O. (2014) Inkljuzyvna osvita. Kh.: Vyd-vo «Ranok».

Kunenko, L. O. Vykorystannja art-pedaghoghichnykh metodiv u korekcijnij pedaghoghici. Naukovi praci Chornomorsjkogho DU im. P.Moghyly. Serija: Pedaghoghika, V. 108, Vyp. 95, 47-50.

Matveieva, N. (2018) Inclusive Education in Schools Organizational-Pedagogical Aspect of the Problem Jornal of V.Stefanyk PNU. Vol. 5, No 1, 80-88.

Kosteczka, A.O. (2014) Medyko-organizacijna texnologiya optymizaciyi monitoryngu porushen zoru u shkolyariv (Extended abstract of Candidate's thesis) Retrived from: https://nmapo.edu.ua/zagruzka/DrAr/ArKostecka.pdf

$\begin{array}{ll}\text { Статтю подано до редколегії } & 17.01 .2019 \\ \text { Рекомендовано до друку } & \text { 02.02.2019 p. }\end{array}$ 